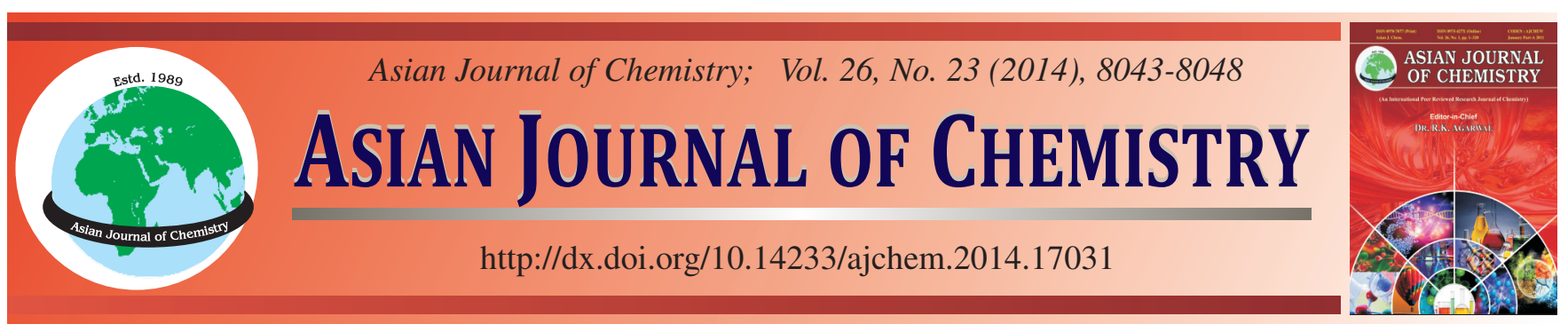

\title{
Optimization of the Microwave Assisted Extraction and Its Comparison with Different Conventional Extraction Methods for Isolation of Stevioside from Stevia rebaudiana
}

\author{
Sumera Javad ${ }^{1, *}$, Shagufta Naz ${ }^{2}$, Saiqa Ilyas ${ }^{1}$, Amna TAriq $^{1}$ and Farah Aslam ${ }^{2}$
}

${ }^{1}$ Department of Botany, Lahore College for Women University, Lahore, Pakistan

${ }^{2}$ Department of Biotechnology, Lahore College for Women University, Lahore, Pakistan

*Corresponding author: E-mail: drsnaz31@ @otmail.com

Received: 14 January 2014;

Accepted: 10 May 2014;

Published online: 15 November 2014;

AJC-16290

\begin{abstract}
Stevioside is a natural acaloric stevioside being extracted from Stevia rebaudiana but 150-200 times sweeter than sucrose. In present study a comparison was made between conventional methods of extraction i.e., soxhlet extraction and cold maceration and modern method of extraction i.e., microwave assisted extraction for the rapid and efficient extraction of stevioside from Stevia rebaudiana. It was found that microwave assisted extraction gave the maximum amount of stevioside $(0.7658 \mathrm{mg} / \mathrm{g}$ of dry leaf powder $)$ while using lesser time of extraction $(120$ seconds $)$ with a little amount of solvent used $(10 \mathrm{~mL} / \mathrm{g})$. Another advantage of the method was the maximum quantity of stevioside was obtained from water which is an environment friendly solvent.
\end{abstract}

Keywords: Extraction, Stevioside, Stevia rebaudiana.

\section{INTRODUCTION}

Stevia rebaudiana, sweet leaf, is a magic plant native to Brazil and Paraguay. It is the member of family Asteraceae. The plant is rich in acaloric sweet glycosides and stevioside is one of them ${ }^{1}$. Other glycosides present are steviolbioside, rebaudioside $\mathrm{A}, \mathrm{B}, \mathrm{C}, \mathrm{D}, \mathrm{E}, \mathrm{F}$ and dulcoside $\mathrm{A}^{2}$. The main cause of the recent interest of the scientists and researchers in all the species of Stevia rebaudiana, are these glycoside ${ }^{3}$.

Stevioside is in fact, anent-kaurenediterpenoid glycoside ${ }^{4}$ which is 150 to 300 times sweeter than sucrose ${ }^{5}$. It has zero caloric value ${ }^{6}$. Traditionally dried leaves of stevia were used in cooking, teas and drinks, but leaves residues and green colour caused discomfort ${ }^{7}$. But now in number of advanced as well as under developed countries people are well aware of importance of stevioside. Stevioside is available on commercial scale in those countries in form of liquid drops,fine powder and as raw leaves to be used as a sweetener. Stevia can replace all artificial sweeteners without any hazardous effect. Safety of using of stevioside as a sweetener depends on the fact that stevioside pass through the digestive system with no any chemical breakdown, this is the reason which controls the sugar level in one's blood ${ }^{8,9}$.

Very first step in making a commercial product like stevioside from plant is extraction ${ }^{10}$. But this step is often abandoned even though it affects both the ultimate quality and quantity of product ${ }^{11}$.
Soxhlet extraction, hot maceration, cold maceration and hydro distillation are some of the examples of the conventional extraction methods used for plant secondary metabolites. These methods involve at first the cell permeation and then dissolving the target compounds ${ }^{12}$. All conventional methods of extraction are time and solvent consuming therefore economically not feasible.

Recently to prevail over these issues, a number of modern techniques have been introduced for the extraction of secondary metabolites from plants. These methods have reduced extraction time, have a lesser amount of solvent consumption and environmental pollution ${ }^{13}$. These methods include pressurized fluid extractions ${ }^{14}$, supercritical fluid extractions ${ }^{15}$ and microwave assisted extraction ${ }^{16,17}$ etc.

Microwaves are used for the extraction of compounds of commercial importance in less time, with lesser solvent and causing comparatively lesser harm to the environment ${ }^{18}$. This method is precise and economic to extract the vegetal products In microwave assisted extraction waves of $300 \mathrm{MHz}$ to 300 $\mathrm{GHz}$ are used ${ }^{19,20}$.

\section{EXPERIMENTAL}

The reported research work was carried out to optimize a rapid and efficient method of extraction to isolate the stevioside from the plant. For this purpose different techniques of extractions i.e., microwave assisted extraction, Soxhlet extraction and cold maceration were used. Qualitative analysis was carried 
out by thin layer chromatography (TLC) as well as high performance liquid chromatography (HPLC) while quantitative analysis of stevioside was done by HPLC alone.

Air dried plant leaves were used as a source material for investigation. Air dried plant parts were ground into a fine powder with the help of the grinder and sieved through sieves of four sizes i.e., 100, 125, 150 and $200 \mu$. One gram of the plant material was weighed accurately each time, for each sample in $10 \mathrm{~mL}$ of the solvent (ethanol, methanol, water and their binary mixtures) for microwave assisted extraction. So microwave assisted extraction for stevioside was carried out in Orient Microwave (OM-55-B9) by using different power levels of microwaves i.e., 100, 200 and 300 W. Samples were irradiated for 10, 20, 30,....120 seconds, respectively. Solvents used for the extraction were water, ethanol, methanol and their combinations. Presence of stevioside was estimated by using TLC. Percentage yield of extract was calculated then and quantity of stevioside was estimated by using HPLC.

Soxhlet extraction and cold maceration were also optimized for the extraction of stevioside to compare the yields of stevioside with that of microwave assisted extraction. Parameters used to optimize the protocols were time of procedure $(5,10,15,20$ and $25 \mathrm{~h})$ as well as solvent volume $(50,100$, 200 and $300 \mathrm{~mL}$ ) and solvent type (Water, ethanol, methanol and their combinations). Ten grams of plant material was taken each time. Extract was made solvent free with the help of the rotary evaporator. Percentage yield was calculated for each sample and the stevioside was quantified by using HPLC again.

Thin layer chromatography (TLC) plates of $20 \mathrm{~cm} \times 20$ $\mathrm{cm}$ size coated with Silica gel $60 \mathrm{~F}_{254}$ (Merk, Germany) were used for the experiment. Spots were applied with fine capillary tubes. Different solvent systems were applied for getting the $\mathrm{R}_{\mathrm{f}}$ values of the standard as well as the samples. But methanol: water (82:18) gave the best results. Plates were visualized by spraying with $10 \% \mathrm{H}_{2} \mathrm{SO}_{4}$ and subsequent heating on the hot plate which produced black spots with stevioside. $\mathrm{R}_{\mathrm{f}}$ values were then compared to identify the stevioside. Further confirmation of the results was obtained with the help of HPLC analysis. HPLC analysis was carried out on HPLC equipment (Shimardzu, Japan) with ODS-C $\mathrm{C}_{18}$ column $(4.6 \mathrm{ID} \times 250 \mathrm{~mm})$ with $5 \mu \mathrm{m}$ pore size and detector, $\mathrm{UV}$-visible at $210 \mathrm{~nm}$. Mobile phase consisted of methanol:water (80:20) with a flow rate of $1 \mathrm{~mL} / \mathrm{min}$. Run time was set at $10 \mathrm{~min}$.

Stevioside standard of HPLC (High Performance Liquid Chromatography) grade (Sigma, CAT\# S3572) was purchased from Shad Chemicals, Lahore, Pakistan. Standard was prepared by mixing $0.1 \mathrm{mg}$ of the powder with $10 \mathrm{~mL}$ of the solvent.

Standard stevioside and mobile phase were of HPLC grade. All the sample solutions were filtered with $0.45 \mu$ pore size microfilters.

The data thus generated were analyzed through one way analysis of variance (ANOVA) and treatments' means were compared for significance by Duncan's New Multiple Range test at $5 \%$ level of significance using Costat computer software.

\section{RESULTS AND DISCUSSION}

Table-1 gives the yield (\%) of stevioside in $\mathrm{mg} / \mathrm{g}$ of leaf powder in two solvents i.e., (100\% ethanol and $100 \%$ water) with $100,125,150$ and $200 \mu$ of leaf powder size, respectively using microwave assisted extraction. When leaf powder of mesh size $100 \mu$ was irradiated with different power levels of microwaves, it was observed that yield of stevioside ranged from 0.0954 to $0.5081 \mathrm{mg}$ per gram of leaf powder in ethanol and 0.1223 to $0.5332 \mathrm{mg}$ per gram of stevioside from water. As the mesh size increased to $125 \mu$, quantity of stevioside also increased ( 0.25 to $0.5333 \mathrm{mg}$ in ethanol and 0.254 to 0.692 $\mathrm{mg}$ per gram in water). While on further increasing the mesh size of leaf powder up to 150 and $200 \mu$, quantity of stevioside was decreased which showed that 150 and $200 \mu$ powder size

\begin{tabular}{|c|c|c|c|c|c|c|}
\hline \multirow{3}{*}{ Solvent used } & \multicolumn{5}{|c|}{$\begin{array}{l}\text { TABLE-1 } \\
\text { OPTIMIZATION OF POWER LEVEL AND MESH SIZE FOR MICROWAVE } \\
\text { ASSISTED EXTRACTION OF STEVIOSIDE FROM Stevia rebaudiana }\end{array}$} & \\
\hline & \multirow{2}{*}{$\begin{array}{l}\text { Power level } \\
\text { (W) }\end{array}$} & \multirow{2}{*}{ Time (min) } & \multicolumn{4}{|c|}{ Quantity of Stevioside } \\
\hline & & & $100 \mu$ & $125 \mu$ & $150 \mu$ & $200 \mu$ \\
\hline \multirow{9}{*}{ Ethanol } & \multirow{3}{*}{100} & 1 & $0.0954^{\mathrm{h}} \pm 0.0004$ & $0.344^{\mathrm{k}} \pm 0.07$ & $0.0338^{\text {hi }} \pm 0.007$ & $0.0132^{\mathrm{d}} \pm 0.001$ \\
\hline & & 2 & $0.1223^{\mathrm{gh}} \pm 0.0002$ & $0.371^{\mathrm{i}} \pm 0.08$ & $0.0364^{\mathrm{hi}} \pm 0.01$ & $0.0101^{\mathrm{d}} \pm 0.006$ \\
\hline & & 3 & $0.2339^{\mathrm{de}} \pm 0.0005$ & $0.293^{\mathrm{m}} \pm 0.01$ & $0.0228^{i} \pm 0.01$ & $0.0338^{\mathrm{d}} \pm 0.014$ \\
\hline & \multirow{3}{*}{200} & 1 & $0.2359^{\mathrm{de}} \pm 0.0009$ & $0.511^{\mathrm{f}} \pm 0.06$ & $0.22^{\mathrm{d}} \pm 0.03$ & $0.152^{\mathrm{c}} \pm 0.03$ \\
\hline & & 2 & $0.5081^{\mathrm{a}} \pm 0.005$ & $0.533^{\mathrm{d}} \pm 0.03$ & $0.3162^{b} \pm 0.02$ & $0.1965^{\mathrm{c}} \pm 0.03$ \\
\hline & & 3 & $0.3951^{\mathrm{b}} \pm 0.005$ & $0.521^{\mathrm{e}} \pm 0.02$ & $0.2431^{\mathrm{cd}} \pm 0.008$ & $0.1813^{\mathrm{c}} \pm 0.05$ \\
\hline & \multirow{3}{*}{300} & 1 & $0.173^{\mathrm{fg}} \pm 0.012$ & $0.317^{1} \pm 0.005$ & $0.0206^{i} \pm 0.005$ & $0.0429^{\mathrm{d}} \pm 0.01$ \\
\hline & & 2 & $0.211^{\mathrm{def}} \pm 0.009$ & $0.323^{1} \pm 0.013$ & $0.0285^{\mathrm{i}} \pm 0.002$ & $0.0627^{\mathrm{d}} \pm 0.013$ \\
\hline & & 3 & $0.247^{\mathrm{d}} \pm 0.017$ & $0.251^{\mathrm{n}} \pm 0.013$ & $0.0285^{\mathrm{i}} \pm 0.01$ & $0.0129^{\mathrm{d}} \pm 0.004$ \\
\hline \multirow{9}{*}{ Water } & \multirow{3}{*}{100} & 1 & $0.2004^{\mathrm{efg}} \pm 0.001$ & $0.403^{\mathrm{h}} \pm 0.02$ & $0.0912^{\mathrm{e}} \pm 0.012$ & $0.0250^{\mathrm{d}} \pm 0.02$ \\
\hline & & 2 & $0.2008^{\mathrm{efg}} \pm 0.0006$ & $0.356^{\mathrm{j}} \pm 0.03$ & $0.0899^{\mathrm{ef}} \pm 0.007$ & $0.0312^{\mathrm{d}} \pm 0.002$ \\
\hline & & 3 & $0.1223^{\text {gh }} \pm 0.0015$ & $0.259^{n} \pm 0.02$ & $0.0450^{\mathrm{ghi}} \pm 0.025$ & $0.0340^{\mathrm{d}} \pm 0.005$ \\
\hline & \multirow{3}{*}{200} & 1 & $0.2657^{\mathrm{c}} \pm 0.035$ & $0.541^{\mathrm{c}} \pm 0.01$ & $0.2730^{c} \pm 0.025$ & $0.2631^{\mathrm{b}} \pm 0.05$ \\
\hline & & 2 & $0.5332^{\mathrm{a}} \pm 0.06$ & $0.693^{a} \pm 0.01$ & $0.4328^{a} \pm 0.004$ & $0.4001^{\mathrm{a}} \pm 0.35$ \\
\hline & & 3 & $0.4116^{b} \pm 0.055$ & $0.593^{\mathrm{b}} \pm 0.04$ & $0.2654^{\mathrm{c}} \pm 0.04$ & $0.2921^{\mathrm{b}} \pm 0.07$ \\
\hline & \multirow{3}{*}{300} & 1 & $0.1910^{\mathrm{fg}} \pm 0.0011$ & $0.338^{\mathrm{k}} \pm 0.03$ & $0.0682^{\mathrm{fgh}} \pm 0.04$ & $0.0501^{\mathrm{d}} \pm 0.04$ \\
\hline & & 2 & $0.3020^{c} \pm 0.198$ & $0.467^{\mathrm{g}} \pm 0.05$ & $0.0752^{\text {efg }} \pm 0.015$ & $0.0639^{d} \pm 0.003$ \\
\hline & & 3 & $0.2000^{\mathrm{efg}} \pm 0.09$ & $0.358^{\mathrm{j}} \pm 0.02$ & $0.0639^{\text {efgh }} \pm 0.001$ & $0.0047^{\mathrm{d}} \pm 0.05$ \\
\hline
\end{tabular}


is not suitable for microwave assisted extraction of stevioside as it is too large to be used.

Particle size of matrix for microwave assisted extraction may vary from $100 \mu$ to $5 \mathrm{~mm}$ but small matrix size increases the surface area of the particles of plant matrix thus increasing the contact of solvent molecules and matrix particles ${ }^{21}$. For the extraction of withenolides fine particles were selected for the microwave assisted extraction by Kaufman et al. ${ }^{22}$.

It is also clear from Table-1 that maximum yield of stevioside was obtained from microwaves of $200 \mathrm{~W}$ and 120 seconds of irradiation for both particle sizes showing that it is the optimum power level and time of extraction for microwave assisted extraction of stevia leaf powder. On further increasing the power level of microwaves to $300 \mathrm{~W}$ for $2 \mathrm{~min}$, yield of stevioside reduced.

After that the irradiation time of microwaves was optimized, details of which are given in Table-2. Two solvents (water and ethanol) were used for 10, 20, 30, ......, 200 seconds of microwave irradiation time. The results showed that time of irradiation significantly influenced the extraction of stevioside from stevia leaf powder. Yield of stevioside in extracts at different irradiation times ranged between 0.0702 to $0.5465 \mathrm{mg}$ in ethanol while from 0.1011 to $0.7658 \mathrm{mg}$ in water. Maximum amount of yield was obtained from 120 seconds of microwaves irradiation i.e., 0.5465 and $0.7658 \mathrm{mg}$ in ethanol and water (Figs. 1 and 2, respectively). The yield of stevioside decreased with further increase in irradiation time of the extracts which was estimated to be $0.3665 \mathrm{mg}$ in water at $200 \mathrm{sec}$ as compared to the $0.7658 \mathrm{mg}$ of stevioside in water extract of stevia leaf powder at $120 \mathrm{~s}$ of microwaves irradiation. Similarly in ethanol after irradiation of the sample with $200 \mathrm{~s}$, yield of stevioside was just $0.2883 \mathrm{mg} / \mathrm{g}$ of the leaf powder.

Time to power combination is a very good strategy for optimizing extraction of any compound using microwave assisted extraction. Low power of irradiation with long exposure is usually preferable over extractions with high power of irradiation with less exposure as it may cause degradation of the target compound, explosion due to overheating of the solvent or solvent losses ${ }^{23,24}$. Moreover lower power levels cause the slow cell wall destruction and gradual release of exudates so making microwave assisted extraction more selective for the target compound ${ }^{17,25,26}$.

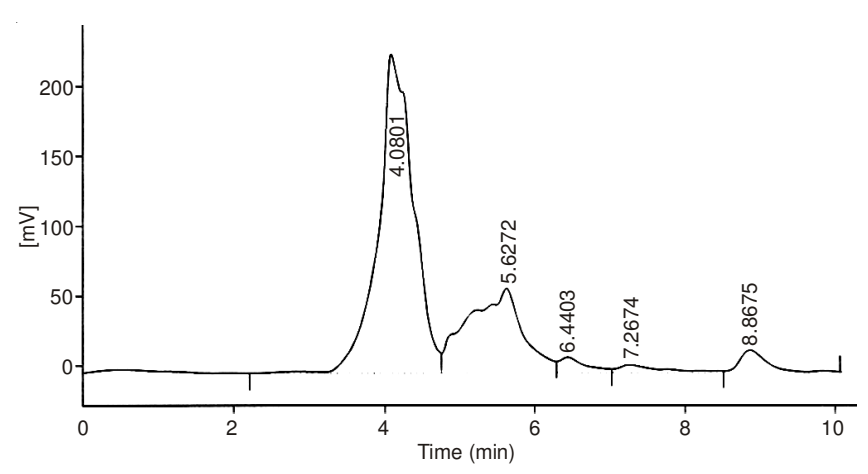

Fig. 1. HPLC chromatogram of microwave assisted extraction with $125 \mu$ particles with $200 \mathrm{~W}$ microwaves for $120 \mathrm{~s}$ in ethanol

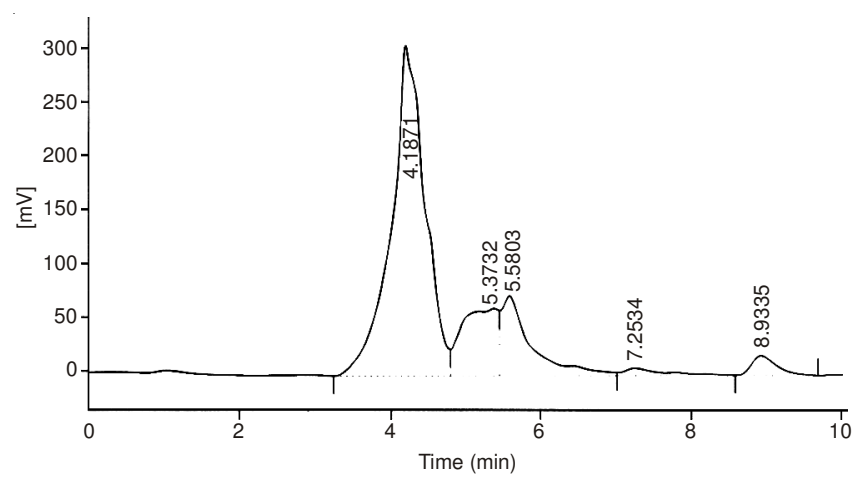

Fig. 2. HPLC chromatogram of microwave assisted extraction with $125 \mu$ particles with $200 \mathrm{~W}$ microwaves for $120 \mathrm{~s}$ in water

An experiment was conducted to find the effect of time and solvent volume on extraction of stevioside through Soxhlet extraction and cold maceration (Table-3). Percentage yield of extract ranged from 0.3 to $61.42 \%$ of plant material. Only 12.96 to $19.06 \%$ of extract was obtained in all the solvent volume treatments in $5 \mathrm{~h}$ of extraction which showed that this is the inadequate time for Soxhlet extraction. It gave a maximum of $45 \%$ of extract in $400 \mathrm{~mL}$ of the ethanol after $10 \mathrm{~h}$ of extraction. Moreover maximum amount of extract was obtained after $15 \mathrm{~h}$ of extraction in $300 \mathrm{~mL}$ of solvent i.e., $61.42 \%$ of extraction as well as $0.272 \mathrm{mg}$ of stevioside (Fig. 3). Then after 20 to $25 \mathrm{~h}$ of extraction, 60.98 and $60.08 \%$ of extract was obtained in $300 \mathrm{~mL}$ of solvent, respectively.

TABLE-2

OPTIMIZATION OF TIME FOR MICROWAVE ASSISTED EXTRACTION OF STEVIOSIDE FROM Stevia rebaudiana

\begin{tabular}{ccccc}
\hline \multirow{2}{*}{$\begin{array}{c}\text { Time taken for extraction } \\
\text { (sec) }\end{array}$} & \multicolumn{2}{c}{$\begin{array}{c}\text { \%age Yield of extract at } \\
200 \mathrm{~W} \text { of microwaves in }\end{array}$} & \multicolumn{2}{c}{$\begin{array}{c}\text { Yield of stevioside (mg/g leaf powder) } \\
\text { at 200 W of microwaves in }\end{array}$} \\
\cline { 2 - 5 } & Ethanol & Water & Ethanol & Water \\
\cline { 2 - 5 } 10 & 29 & 31 & $0.0741^{1} \pm 0.0018$ & $0.1011^{1} \pm 0.015$ \\
30 & 29 & 32 & $0.0702^{\mathrm{l}} \pm 0.0014$ & $0.1139^{\mathrm{l}} \pm 0.009$ \\
60 & 32 & 39 & $0.1931^{\mathrm{k}} \pm 0.016$ & $0.2450^{\mathrm{k}} \pm 0.019$ \\
90 & 72 & 75 & $0.4773^{\mathrm{e}} \pm 0.003$ & $0.5312^{\mathrm{g}} \pm 0.017$ \\
120 & 78 & 81 & $0.5120^{\mathrm{bc}} \pm 0.001$ & $0.5521^{\mathrm{fg}} \pm 0.021$ \\
150 & 85 & 88 & $0.5465^{\mathrm{a}} \pm 0.0204$ & $0.7658^{\mathrm{a}} \pm 0.015$ \\
180 & 63 & 70 & $0.3911^{\mathrm{g}} \pm 0.0230$ & $0.6123^{\mathrm{de}} \pm 0.015$ \\
210 & 60 & 65 & $0.5301^{\mathrm{ab}} \pm 0.0016$ & $0.5784^{\mathrm{ef}} \pm 0.038$ \\
& 44 & 51 & $0.2933^{\mathrm{j}} \pm 0.011$ & $0.365^{\mathrm{j}} \pm 0.014$ \\
\hline
\end{tabular}

Each value is mean of five replicate with standard error (mean $\pm \mathrm{S}$. E). Means within a column not sharing a common superscript differ significantly $(\mathrm{P}<0.05)$ according to Duncan's new multiple range test 
TABLE-3

OPTIMIZATION OF TIME FOR SOXHLET EXTRACTION AND COLD MACERATION OF STEVIOSIDE FROM Stevia rebaudiana

\begin{tabular}{|c|c|c|c|c|c|c|}
\hline S. No. & $\begin{array}{c}\text { Time of } \\
\text { Extraction }(\mathrm{h})\end{array}$ & $\begin{array}{l}\text { Solvent volume } \\
(\mathrm{mL})\end{array}$ & $\begin{array}{c}\text { \%age Yield } \\
\text { of leaf extract }\end{array}$ & $\begin{array}{l}\text { Quantity of Stevioside } \\
\text { mg/g of leaf powder }\end{array}$ & $\begin{array}{c}\text { \%age Yield of } \\
\text { leaf extract }\end{array}$ & $\begin{array}{l}\text { Quantity of Stevioside } \\
\text { mg/g of leaf powder }\end{array}$ \\
\hline \multirow{5}{*}{1} & \multirow{5}{*}{1} & & \multicolumn{2}{|c|}{ Soxhlet extraction } & \multicolumn{2}{|c|}{ Cold maceration } \\
\hline & & 100 & 02.30 & $0.00001^{1} \pm 0.001$ & 0.100 & $0.00001^{\mathrm{d}} \pm 1.9 \mathrm{E}-6$ \\
\hline & & 200 & 0.3 .30 & $0.00001^{1} \pm 0.001$ & 0.110 & $0.00001^{\mathrm{d}} \pm 1.0 \mathrm{E}-6$ \\
\hline & & 300 & 0.300 & $0.00001^{1} \pm 0.001$ & 0.100 & $0.00001^{\mathrm{d}} \pm 1.0 \mathrm{E}-6$ \\
\hline & & 400 & 0.300 & $0.00001^{1} \pm 0.001$ & 0.100 & $0.00001^{\mathrm{d}} \pm 3.9 \mathrm{E}-5$ \\
\hline \multirow{3}{*}{2} & \multirow{3}{*}{5} & 100 & 12.96 & $0.0005^{1} \pm 0.0001$ & 04.00 & $0.000114^{\mathrm{d}} \pm 6.9 \mathrm{E}-6$ \\
\hline & & 300 & 14.46 & $0.00012^{1} \pm 0.02$ & 06.00 & $0.00026^{\mathrm{d}} \pm 8.6 \mathrm{E}-05$ \\
\hline & & 400 & 19.06 & $0.0011^{1} \pm 0.002$ & 07.75 & $0.0026^{\mathrm{d}} \pm 2.7 \mathrm{E}-05$ \\
\hline \multirow{4}{*}{3} & \multirow{4}{*}{10} & 100 & 18.06 & $0.0012^{1} \pm 0.002$ & 10.10 & $0.0124^{\mathrm{d}} \pm 0.00016$ \\
\hline & & 200 & 30.00 & $0.113^{\mathrm{h}} \pm 0.0010$ & 11.00 & $0.0282^{\mathrm{d}} \pm 0.0061$ \\
\hline & & 300 & 41.98 & $0.141^{\mathrm{f}} \pm 0.0022$ & 09.80 & $0.0136^{\mathrm{d}} \pm 0.0067$ \\
\hline & & 400 & 45.00 & $0.132^{\mathrm{g}} \pm 0.0013$ & 10.10 & $0.013^{\mathrm{d}} \pm 0.00066$ \\
\hline \multirow{3}{*}{4} & \multirow{3}{*}{15} & 100 & 41.40 & $0.234^{\mathrm{c}} \pm 0.0039$ & 14.50 & $0.0336^{\mathrm{c}} \pm 0.015$ \\
\hline & & 300 & 61.42 & $0.272^{\mathrm{a}} \pm 0.0016$ & 14.10 & $0.0428^{\mathrm{abc}} \pm 0.031$ \\
\hline & & 400 & 60.92 & $0.27^{\mathrm{a}} \pm 0.006$ & 14.00 & $0.0404^{\text {bc }} \pm 0.038$ \\
\hline \multirow{4}{*}{5} & \multirow{4}{*}{20} & 100 & 47.98 & $0.043^{\mathrm{j}} \pm 0.0034$ & 11.30 & $0.05^{\mathrm{abc}} \pm 0.0038$ \\
\hline & & 200 & 43.00 & $0.138^{f} \pm 0.0012$ & 16.20 & $0.048^{\mathrm{abc}} \pm 0.0031$ \\
\hline & & 300 & 60.44 & $0.155^{\mathrm{e}} \pm 0.0034$ & 15.30 & $0.046^{\mathrm{abc}} \pm 0.0028$ \\
\hline & & 400 & 60.98 & $0.168^{\mathrm{d}} \pm 0.0024$ & 15.00 & $0.047^{\mathrm{abc}} \pm 0.0150$ \\
\hline \multirow{4}{*}{6} & \multirow{4}{*}{25} & 100 & 40.44 & $0.1381^{f} \pm 0.002$ & 20.00 & $0.0622^{\mathrm{a}} \pm 0.0021$ \\
\hline & & 200 & 40.80 & $0.1397^{f} \pm 0.009$ & 20.00 & $0.0632^{\mathrm{a}} \pm 0.0142$ \\
\hline & & 300 & 60.80 & $0.105^{\mathrm{i}} \pm 0.0004$ & 20.00 & $0.0602^{\mathrm{ab}} \pm 0.0012$ \\
\hline & & 400 & 58.38 & $0.015^{\mathrm{k}} \pm 0.0005$ & 20.00 & $0.0646^{\mathrm{a}} \pm 0.0031$ \\
\hline
\end{tabular}

Each value is mean of five replicate with standard error (mean \pm S. E). Means within a column not sharing a common superscript differ significantly $(\mathrm{P}<0.05)$ according to Duncan's new multiple range test

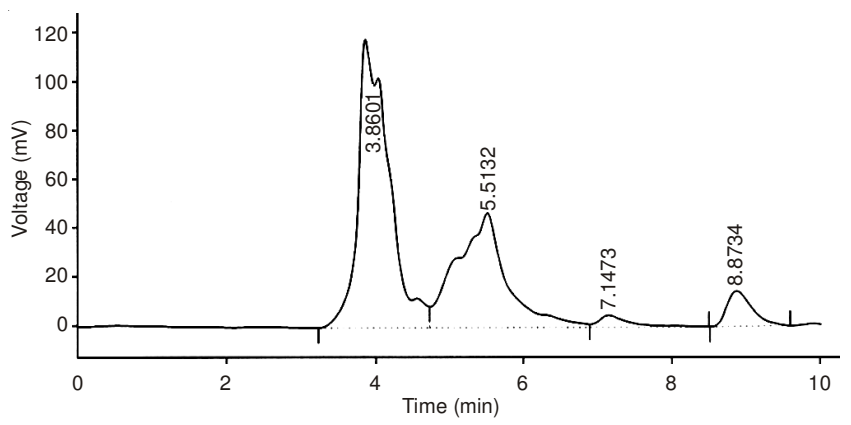

Fig. 3. HPLC chromatogram of Soxhlet extraction with $300 \mathrm{~mL}$ of ethanol and $16 \mathrm{~h}$ of extraction

Amount of plant extract for cold maceration varied between $0.1-20 \%$. A maximum of $20 \%$ of extract and $0.06 \mathrm{mg}$ of stevioside was obtained after $25 \mathrm{~h}$ of cold maceration in 100 , 200 and $300 \mathrm{~mL}$ of the ethanol (Fig. 4). It shows that $25 \mathrm{~h}$ is the optimum time for maximum production of extract from $10 \mathrm{~g}$ of Stevia leaf powder and any increase in the volume of the solvent does not affect the amount of extract further.

Another experiment was set up to find the effect of nature of the solvent on the extraction of stevioside through Soxhlet apparatus, cold maceration and microwave assisted extraction (Table-4). In this experiment ethanol, methanol, their mutual mixtures and their mixtures with water were used to find the maximum percentage yield of stevioside for $15 \mathrm{~h}$ of extraction in $300 \mathrm{~mL}$ of the solvent for Soxhlet extraction and cold maceration and $200 \mathrm{~W}$ power of microwaves for 120 seconds. Maximum stevioside was obtained as $0.7658 \mathrm{mg} / \mathrm{g}$ of leaf powder using water as solvent while in case of soxhlet extraction and cold maceration, maximum quantity of stevioside

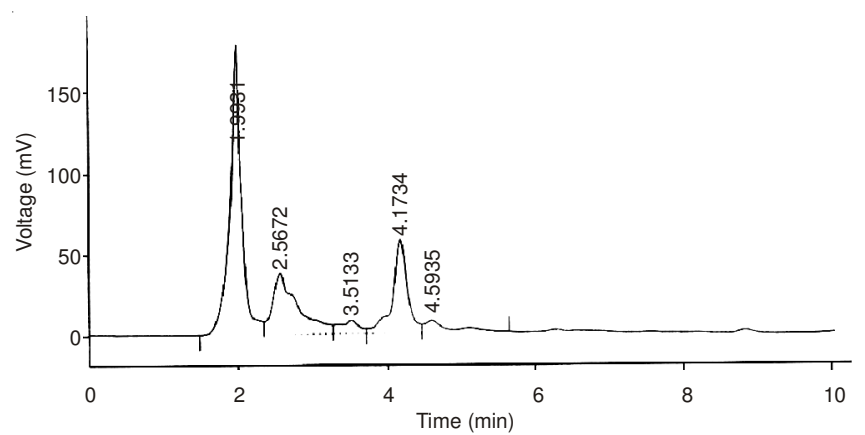

Fig. 4. HPLC chromatogram of cold maceration with $300 \mathrm{~mL}$ of ethanol and $25 \mathrm{~h}$ of cold maceration

obtained was 0.2590 and $0.2632 \mathrm{mg} / \mathrm{g}$ of leaf powder in ethanol:methanol (80:20) and methanol, respectively.

A comparison of all the three methods has been made which showed the optimum yield of stevioside by the Soxhlet extraction, cold maceration and microwave assisted extraction separately (Table- 5). $\mathrm{R}_{\mathrm{f}}$ values of all the extracts showed that fraction of stevioside was present in all samples whether extracted by Soxhlet extraction, cold maceration and microwave assisted extraction, while HPLC studies showed that amount of stevioside ranged from $0.29 \mathrm{mg} / \mathrm{g}$ of leaves to 0.5413 $\mathrm{mg}$ per gram of the powder of dried leaves. Maximum amount of stevioside was observed in microwave assisted extraction of stevia leaves for $120 \mathrm{~s}$ in $10 \mathrm{~mL}$ of the water, used as a solvent while minimum amount of stevioside was obtained by cold maceration of the stevia leaf powder using water as a solvent.

Solvent consumed per gram of the plant material was also least in microwave assisted extraction as $30 \mathrm{~mL}$ of the solvent was consumed to get the optimum yield of stevioside for both 


\begin{tabular}{|c|c|c|c|c|c|c|}
\hline \multirow{3}{*}{ S. No. } & \multicolumn{5}{|c|}{$\begin{array}{l}\text { TABLE-4 } \\
\text { OPTIMIZATION OF SOLVENT TYPE FOR MICROWAVE ASSISTED EXTRACTION, COLD } \\
\text { MACERATION AND SOXHLET EXTRACTION OF STEVIOSIDE FROM Stevia rebaudiana }\end{array}$} & \\
\hline & \multicolumn{3}{|c|}{ Solvent mixture } & \multicolumn{3}{|c|}{ Extraction method for stevioside } \\
\hline & Ethanol & Methanol & Water & Microwave assisted extraction & Cold maceration & Soxhlet extraction \\
\hline 1 & 100 & - & - & $0.5413^{\mathrm{d}} \pm 0.016$ & $0.1801^{\mathrm{c}} \pm 0.0034$ & $0.2768^{\mathrm{a}} \pm 0.016$ \\
\hline 2 & - & 100 & - & $0.5938^{c} \pm 0.07$ & $0.1704^{\mathrm{d}} \pm 0.005$ & $0.2632^{\mathrm{a}} \pm 0.026$ \\
\hline 3 & - & - & 100 & $0.7658^{\mathrm{a}} \pm 0.02$ & $0.0029^{i} \pm 0.0004$ & - \\
\hline 4 & 80 & 20 & - & $0.3873^{\mathrm{f}} \pm 0.02$ & $0.2590^{\mathrm{a}} \pm 0.0044$ & $0.1934^{\mathrm{b}} \pm 0.023$ \\
\hline 5 & 60 & 40 & - & $0.3875^{\mathrm{f}} \pm 0.01$ & $0.2173^{b} \pm 0.0037$ & $0.1011^{\mathrm{e}} \pm 0.013$ \\
\hline 6 & 40 & 60 & - & $0.2639^{i} \pm 0.02$ & $0.0715^{\mathrm{f}} \pm 0.0016$ & $0.1735^{\text {bcd }} \pm 0.018$ \\
\hline 7 & 20 & 80 & & $0.2732^{\mathrm{hi}} \pm 0.01$ & $0.0429^{g} \pm 0.0016$ & $0.1540^{\mathrm{cd}} \pm 0.018$ \\
\hline 8 & - & 80 & 20 & $0.2755^{\mathrm{h}} \pm 0.02$ & $0.1339^{\mathrm{e}} \pm 0.0036$ & $0.1401^{\text {cde }} \pm 0.023$ \\
\hline 9 & - & 60 & 40 & $0.2621^{\mathrm{i}} \pm 0.03$ & $0.0435^{\mathrm{g}} \pm 0.0016$ & $0.1562^{\mathrm{bcd}} \pm 0.024$ \\
\hline 10 & - & 40 & 60 & $0.4328^{\mathrm{e}} \pm 0.02$ & $0.0133^{\mathrm{h}} \pm 0.0008$ & $0.1591^{\mathrm{bcd}} \pm 0.031$ \\
\hline 11 & - & 20 & 80 & $0.5033^{\mathrm{d}} \pm 0.02$ & $0.1304^{\mathrm{e}} \pm 0.0074$ & $0.1783^{\mathrm{bc}} \pm 0.014$ \\
\hline 12 & 80 & - & 20 & $0.3162^{\mathrm{g}} \pm 0.02$ & $0.0422^{g} \pm 0.0016$ & $0.1729^{\mathrm{bcd}} \pm 0.019$ \\
\hline 13 & 60 & - & 40 & $0.3875^{\mathrm{f}} \pm 0.03$ & $0.0026^{\mathrm{i}} \pm 0.0002$ & $0.1923^{b} \pm 0.021$ \\
\hline 14 & 40 & - & 60 & $0.5181^{\mathrm{d}} \pm 0.01$ & $0.0004^{i} \pm 0.0007$ & $0.1339^{\mathrm{de}} \pm 0.019$ \\
\hline 15 & 20 & - & 80 & $0.7012^{\mathrm{a}} \pm 0.02$ & $0.0004^{\mathrm{i}} \pm 0.0007$ & $0.1682^{\mathrm{bcd}} \pm 0.047$ \\
\hline
\end{tabular}

Each value is mean of five replicate with standard error (mean \pm S. E). Means within a column not sharing a common superscript differ significantly $(\mathrm{P}<0.05)$ according to Duncan's new multiple range test

\begin{tabular}{|c|c|c|c|c|c|c|}
\hline \multirow[b]{3}{*}{ Method Name } & \multirow{3}{*}{$\begin{array}{c}\text { Leaf } \\
\text { powder }(\mathrm{g})\end{array}$} & \multirow{3}{*}{$\begin{array}{l}\text { Time for } \\
\text { extraction }\end{array}$} & \multirow{3}{*}{$\begin{array}{c}\text { TABLE-5 } \\
\text { ACTION METHOD } \\
\begin{array}{c}\text { Solvent consumed } \\
\text { Per gram of plant } \\
\text { powder (mL) }\end{array}\end{array}$} & \multirow[b]{3}{*}{ Type of solvent } & \multirow[b]{3}{*}{$R_{f}$ value } & ebaudiana \\
\hline & & & & & & Quantity of stevioside \\
\hline & & & & & & By HPLC (mg/g of the leaf) \\
\hline \multirow{3}{*}{ Soxhlet } & \multirow{3}{*}{10} & \multirow{3}{*}{$16 \mathrm{~h}$} & \multirow{3}{*}{300} & Ethanol & 0.94 & $0.2768^{\mathrm{d}} \pm 0.016$ \\
\hline & & & & Methanol & 0.94 & $0.2632^{\mathrm{d}} \pm 0.026$ \\
\hline & & & & Water & - & - \\
\hline \multirow{3}{*}{ Cold maceration } & \multirow{3}{*}{10} & \multirow{3}{*}{$24 \mathrm{~h}$} & \multirow{3}{*}{300} & Ethanol & 0.94 & $0.2022^{\mathrm{e}} \pm 0.003$ \\
\hline & & & & Methanol & 0.94 & $0.1701^{\mathrm{e}} \pm 0.005$ \\
\hline & & & & Water & 0.94 & $0.0029^{f} \pm 0.0004$ \\
\hline \multirow{4}{*}{$\begin{array}{c}\text { Microwave } \\
\text { assisted extraction }\end{array}$} & \multirow{4}{*}{1} & \multirow{4}{*}{$120 \mathrm{sec}$} & \multirow{4}{*}{10} & Ethanol & 0.94 & $0.5413^{\mathrm{c}} \pm 0.016$ \\
\hline & & & & Methanol & 0.94 & $0.5938^{\mathrm{b}} \pm 0.07$ \\
\hline & & & & Water & 0.94 & $0.7658^{\mathrm{a}} \pm 0.02$ \\
\hline & & & & Standard & 0.92 & - \\
\hline
\end{tabular}

Each value is mean of five replicate with standard error (mean \pm S. E). Means within a column not sharing a common superscript differ

significantly $(\mathrm{P}<0.05)$ according to Duncan's new multiple range test

conventional methods used i.e., Soxhlet extraction and cold maceration, while it was $10 \mathrm{~mL}$ per gram of plant material for microwave assisted extraction.

Solvent choice and solvent volume are two other important factors in the extraction experiments particularly in microwave assisted extraction. In addition, maximum amount of stevioside was obtained after 16 and $24 \mathrm{~h}$ of extraction in Soxhlet extraction and cold maceration, respectively, and it took just $120 \mathrm{~s}$ to extract $0.7658 \mathrm{mg}$ of stevioside from same amount of leaf powder by microwave assisted extraction. Results can be interpreted in terms of two main capabilities of the water as a solvent i.e., solubility of stevioside in water is maximum and water is most efficient polar solvent in regard to its dielectric constant to absorb microwaves energy, dissipate it in the external environment and finally exudation of stevioside from the cells of leaves. In any extraction experiment solvent volume should be enough to ensure maximum solvent to matrix contact $^{21}$. In conventional extraction methods, usually higher volumes of solvents are required for better results but in microwave assisted extraction usually solvent volume ranges from 10-30 $\mathrm{mL}$ per gram of the plant sample ${ }^{22}$.

\section{ACKNOWLEDGEMENTS}

Funds for the present study were provided by the Higher Education Commission of Pakistan while facilities of Department of Biotechnology, Lahore College for Women University, Lahore, Pakistan were used.

\section{REFERENCES}

1. J.M.C. Geuns, Phytochemistry, 64, 913 (2003).

2. E.J. Kennelly, in ed.: A.D. Kinghorn, Stevia, The genus Stevia. Medicinal and Aromatic Plants-Industrial profiles, vol. 19, p. 68 (2002).

3. D.D. Soejarto, in ed.: A.D. Kinghorn, Taylor and Francis, London and New York, p. 40 (2002).

4. I.E. Brandle and P.G. Telmer, Phytochemistry, 68, 1855 (2007).

5. M.S. Uddin, S.H.C. Mohammad, M.M.H.K. Mohammad, U. Belal, A. Romel and A.B. Mohammad, Afr. J. Bot., 5, 1238 (2006).

6. A.S. Dacome, C.C. da Silva, C.E.M. da Costa, J.D. Fontana, J. Adelmann and S.C. da Costa, Process Biochem., 40, 3587 (2005).

7. V.P. Tsanava, G.P. Sardzhveladze and L.G. Kharebava, SubtropicheskieKul'Tury, 3, 64 (1991).

8. A.M. Hutapea, C. Toskulkao, D. Buddhasukh, P. Wilairatand T. Glinsukon, J. Clin. Biochem. Nutr., 23, 177 (1997).

9. A. Wheeler, A.C. Boileau, P.C. Winkler, J.C. Compton, I. Prakash, X. Jiang and D.A. Mandarino, Food Chem. Toxicol., 46, 54 (2008). 
10. T. Jain, V. Jain, R. Panday and A. Vyas, Asian J. Res. Chem., 2, 19 (2009).

11. V. Mandal, Y. Mohan and S. Hemalatha, Pharmacog. Rev., 1, 7 (2007).

12. D. Jyothi, S. Khanam and R. Sultana, Int. J. Pharm. Pharm. Sci., 2, 46 (2010)

13. S. Pan, R. Aebersold, R. Chen, J. Rush, D.R. Goodlett, M.W. McIntosh, J. Zhang and T.A. Brentnall, J. Proteome Res., 8, 787 (2009).

14. X. Chaudot, A. Tambute and M. Caude, J. Chromatogr. A, 866, 231 (2000)

15. H. Sonnenschein, I. Germanus and P. Harting, Chem. Eng. Technol., 74, 270 (2002)

16. E. Martino, I. Ramaiola, M. Urbano, F. Bracco and S. Collina, $J$. Chromatogr. A, 1125, 147 (2006)

17. Y. Zhang, X.F. Li, G.S. Liu and Y.F. Chen, J. Northwest Sci-Tech. Univ. Agric. For. (Nat. Sci. Ed.), 35, 111 (2007).
18. M. Soylak, M. Tuzen, A.S. Souza, M.G.A. Korn and S.L.C. Ferreira, J. Hazard. Mater., 149, 264 (2007).

19. C. Deng, X. Xu, N. Yao, N. Li and X. Zhang, Anal. Chim. Acta, 556, 289 (2006).

20. W.H. Xiao, L.J. Han and B. Shi, Sep. Purif. Technol., 62, 614 (2008).

21. C. Sparr Eskilsson and E. Björklund, J. Chromatogr. A, 902, 227 (2000).

22. B. Kaufmann, P. Christen and J. Veuthey, Phytochem. Anal., 12, 327 (2001).

23. G. Raman and V.G. Gaikar, Ind. Eng. Chem. Res., 41, 2521 (2002).

24. Y.Y. Shu, M.Y. Ko and Y.S. Chang, Microchem. J., 74, 131 (2003).

25. J. Fornal and R. Jaroch, Fat Sci. Technol., 94, 192 (1992).

26. M. Desai, J. Parikh and P.A. Parikh, Sep. Purif. Rev., 39, 1 (2010). 